\title{
Literacy education for low-educated second language learning adults in multilingual contexts: the case of Luxembourg
}

\author{
Jinyoung Choi ${ }^{*}$ and Gudrun Ziegler ${ }^{2}$
}

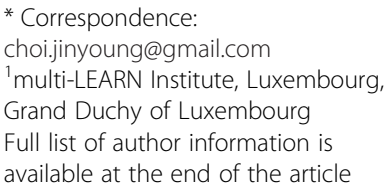

* Correspondence: choi.jinyoung@gmail.com 1 multi-LEARN Institute, Luxembourg, Grand Duchy of Luxembourg Full list of author information is available at the end of the article

\begin{abstract}
Mastery of literacy skills in the language(s) of the host country is considered a key element for the successful integration of immigrants. The current paper focuses on possibly one of the most challenging aspects of the issues of linguistic integration of immigrants, i.e., literacy acquisition by "low-literate" adult immigrants in a "multilingual" environment such as Luxembourg. It documents Luxembourg's current state of literacy education policies and practices with regard to low-literate adult L2 learners. Also, it contains a participatory observation on a French literacy course in Luxembourg in order to look into the actual implementation and effectiveness of such courses in more detail. In doing so, we look into the relevant policies and practices of two other multilingual countries, i.e., Canada and Belgium, in order to situate the present practices of Luxembourg within larger contexts and provide insights into how to promote better policy and education options for low-literate adult immigrants in Luxembourg.
\end{abstract}

Keywords: Adult literacy education; Low educated adult second language and literacy acquisition (LESLLA); Second language acquisition; Multilingual contexts; Luxembourg

\section{Background}

Importance of linguistic integration in the context of migration

International migration has become a common practice world-wide, and the issues of integration and adaptation of foreigners have emerged as being crucial for the immigrants themselves and for the maintenance of the host society. Linguistic integration and mastery of literacy skills in the language(s) of the host country are considered a key element among many success factors in integration. Without being able to communicate, read and write in the language(s) of the country of destination, it is very hard to get a job, receive further education, or build up community relationships (Wallace 1992, Grieve 2007). In this sense, Bialystok (2001) remarks that literacy skills are essential to the life in societies. At the same time, mastery of literacy is important for the receiving society as well, as dubbed "adult literacy is crucial to the economic performance of industrialized nations" and "inadequate levels of literacy among a broad section of the population potentially threaten the strength of economies and the social cohesion of nations" (Organization for Economic Co-operation and Development 1995:13).

(c) 2015 Choi and Ziegler. This is an Open Access article distributed under the terms of the Creative Commons Attribution License (http://creativecommons.org/licenses/by/4.0), which permits unrestricted use, distribution, and reproduction in any medium, provided the original work is properly credited. 
Challenges of low-educated second language learners in multilingual contexts

Among the immigrant groups, low-educated adults go through greater challenges in achieving linguistic integration to the new environment. They are so-called LESLLA (Low-Educated adult Second Language and Literacy Acquisition) learners, consisting of those who lack the ability to read and write in the script of their mother tongue (L1) or whose ability is below average primary school level (Van de Craats et al. 2006). They usually had to stop their education due to family responsibilities, ill health, or war. Thus, some of them learn to read and write for the first time in their life in a second language (L2).

According to previous research on illiterate or low-literate adult L2 learners, adult learners who have minimal formal schooling do not have explicit and conscious awareness of linguistic units such as phonemes, morphemes, and words (Young-Scholten and Strom 2006, Kurvers et al. 2007, Onderdelinden et al. 2009). Also, they may be unfamiliar with classroom interaction and lack what is often dubbed "study skills", such as organizing papers in a binder, dating new papers, reviewing new material, or doing homework. When they learn an L2, they show slower progress (Reder and Cohn 1984) and are more prone to fossilization (Selinker 1972).

Particularly, they may run into a bigger problem in multilingual countries like Luxembourg, which has three official languages: Luxembourgish, French, and German. Immigrants in Luxembourg are exposed not only to the spoken sounds of those languages, but also to the written forms of German and French in daily newspapers and administrative documents. In this multilingual and writing-heavy situation, LESLLA people may experience far more severe confusion, frustration, and a sense of being lost than those who reside in monolingual settings.

\section{Our project multi-LITERACIES}

So far, there has been little attention paid to LESLLA immigrants in multilingual settings, and particularly in Luxembourg. Our three-year project, entitled the "Project multi-LITERACIES" intends to bring to discussion how to identify the issues and needs of LESLLA learners, and how to promote their "literacy" in the written languages of Luxembourg. Particularly, the current paper, as part of the Project multi-LITERACIES, documents Luxembourg's current state of linguistic integration policies and practices with regard to low-literate immigrants. We will give an overview of the development of integration policies and adult language education framework in Luxembourg. Furthermore, as the actual implementation and effectiveness of adult literacy education in Luxembourg has not been well-documented, we will also present, as a case study, our observations and findings on a French literacy course in Luxembourg. It will help us to better understand the current situation of adult L2 literacy education in Luxembourg and propose recommendations for a better policy and practice.

In doing so, we will also look into linguistic integration and education policies and practices of two other multilingual countries, i.e., Canada and Belgium, in order to situate the present state of Luxembourg within a larger context and provide insights into how to promote better policy and education options for literacy training for LESLLA immigrants in Luxembourg. The two countries are selected because they are known to have had a longer history of literacy education for immigrants among the countries that 
maintain a policy of multilingualism. Given that literacy education for immigrants can be provided in two types of adult education: either in L2 education centers or in general adult education centers, our points of comparison will address the following three questions:

- Are there separate and independent programs available for LESLLA literacy education in the country of focus? Or is LESLLA literacy education integrated to general adult education that is designed for the native-born population?

- How systematic and uniform are (separate or integrated) LESLLA programs across the country, in terms of curriculum, assessment, and teacher training?

- What is the impact of the country's policy of multilingualism on implementing (separate or integrated) LESLLA literacy education?

This paper is organized as follows. Sections 'Canada' and 'Belgium' discuss the linguistic integration policies and implementation of adult (L2) literacy training in Canada and Belgium, respectively. Section 'Luxembourg' provides an overview of development of integration polices, together with adult language programs in Luxembourg. In section 'A case study', we introduce, as a case study, our observation on a French literacy course organized by a non-profit organization in Luxembourg. Section 'Findings and recommendations' and 'Concluding remarks' contain the findings, recommendations and conclusions of the paper.

\section{Canada}

\section{Background of bilingualism and adult literacy education in Canada}

Canada has had two official languages since the birth of the country, recognizing both French and English at the federal level. English is widely spoken in the majority of the provinces and territories, while French is spoken mainly in Quebec. Canada's bilingualism is considered territorial bilingualism, in which "each language group finds itself mostly within its own politically defined territory, with the two (or more) languages having official status in their own territory" (Hamers and Blanc 2000). In the 1960s, as an attempt to avoid a polarization of Canada and Quebec, the federal government reinforced bilingualism with the 1969 Official Languages Act that guarantees federal government services in the official language of the people's choice and protects minority language rights. According to the 1969 legislation, several provinces began to implement their own language policies, some of which launched adult basic education (or ABE) and literacy training (Shohet 2001).

As Canada has no federal department of education, $\mathrm{ABE}$ and literacy training are conducted in each province and territory in both the formal sector (such as at schools, community colleges, or work sites) and the private sector (such as community-based organizations, cultural communities, and family centers). Training in the formal sector usually leads to certification. In 1999, more than 800 formal and private programs were involved in literacy in Canada, while their practices of adult literacy training in ten provinces and three territories remained uneven. It is reported that the provinces with the strongest commitment to adult literacy training are Ontario, Alberta, and British Columbia (Center for Literacy of Quebec 2008). 
Whereas implementation of $\mathrm{ABE}$ and literacy education is mainly done through provinces and territories, the federal government runs, through the Department of Citizenship and Immigration, the Language Instruction for Newcomers to Canada (LINC) program. It was launched in 1992, and supports language training in English and French to adult newcomers to help them integrate into Canada. An immigrant who is granted permanent residence can first take an assessment test at a language assessment center of the LINC program of his residence. Then the staff of the language center provides him or her with a referral to a course that best fits, including literacy learning. More than 60,000 newcomers are benefiting from the LINC every year (Citizenship and Immigration Canada 2013).

\section{National surveys on literacy in Canada}

One of the good provisions in Canada concerning adult literacy education is that there have been several national surveys on adult literacy as a means to create an infrastructure for adult literacy education across provinces in Canada. They are the 1989 Survey of Literacy Skills Used in Daily Activities (LSUDA), the 1994 International Adult Literacy Survey (IALS), and the 2003 International Adult Literacy and Skills Survey (IALSS). The 1989 LSUDA, in both English and French, measured the literacy and numeracy skills of more than 900 adults ranging in age from sixteen to sixty-nine. The 1994 IALS, sponsored by the Canadian government and OECD, supplied an updated measure of Canada's adult literacy skills, and promoted a broader concept of literacy, such that "literacy is not a simple dichotomy that distinguishes those who have it from those who do not. Rather, it is a continuous distribution of abilities that depends on the type of information and the complexity of the tasks presented". The 2003 IALSS presents that among $42 \%$ of adults who are assessed low-literate, $60 \%$ of them are immigrants and $37 \%$ are the native-born population (Statistics Canada et al. 2005).

\section{National guideline for a curriculum or a test for LESLLA learners: Canadian Language Benchmarks}

Canada's adult (L2) literacy training ensures uniform curriculum thanks to Canadian Language Benchmarks (CLB), a standardized assessment tool and course curriculum. CLB was published in 2000 and revised in 2012, which is designed to help develop a curriculum or a test for LESLLA learners in both English and French. It first defines the category of "ESL/FSL literacy learner" as having "up to eight years of schooling who have not acquired study skills and may have preconceived notions of reading and writing that may hinder progress in class and anyone who comes from a country with a non-Roman alphabet whether or not they are literate in their first language." It also specifies that ESL/FSL literacy courses should enable learners to transit smoothly to ESL/FSL courses or ABE courses. Center for Canadian Language Benchmarks (2000) offers an extensive guide about what kind of skills are to be included in the curriculum for each phase or step of literacy training. It suggests that an ESL/FSL literacy course should include basic numeracy skills as well as pre-reading/writing skills, such as the concept that printed forms, convey meaning, and the study skills as to how to hold a pencil, make pencil strokes and draw the alphabetic characters.

While Center for Canadian Language Benchmarks (2000) is a very good source for any institution to prepare a literacy course for LESLLA learners, the Center for Literacy 
of Quebec (2008) acknowledges several weaknesses of the current adult ESL/FSL literacy training in Canada. First, there are no ideal assessment tools for ESL/FSL literacy because standardized tests are not optimal for LESLLA learners with little schooling. Also, testing LESLLA learners' literacy levels in L1 is desirable, but difficult to be implemented. Second, the Center for Literacy of Quebec (2008) points out that ESL literacy teachers are poorly paid and without appropriate teaching materials and training (Ontario Literacy Coalition 2007). Finally, funding resources are limited for the field of ESL/FSL literacy, even though investment is crucial in developing "assessment, teacher training and professional development, best practices, demographic studies, classroom materials, class aides, day care, and more free classes".

\section{Belgium}

This section discusses the policies and practices of adult (L2) literacy education in the two language communities (i.e., Dutch and French) of Belgium.

\section{Belgium's multilingualism and development of adult literacy education}

Like Canada, Belgium also maintains a territorial multilingualism. French is spoken in two of the three communities of Belgium, namely, Brussels and Wallonia. Dutch is spoken in the north-west part of Belgium, called Flanders. German is mainly used near the German border on the east. Belgium, as a federal state, has different policies on adult education including literacy in different communities (Maroun 2007). That is, each community is directly responsible for adult education in general and literacy in particular.

The Flemish community has developed a governmental-level framework for DSL (Dutch as a second language) literacy education, independently of general adult basic education, since the 1990s (Backs 2008). The two round table conferences on DSL in 1997 and 2002 respectively, were important occasions that brought policy makers and educators together in order to discuss how to build up a provision of DSL that is systemized and uniform across the Flemish community.

According to the policies which were formed in the two round table conferences, two types of adult education provisions were created: the centers for adult education (CAE, Centra voor volwassenenonderwijs) and the centers for adult basic education (CABE, Centra voor basiseducatie). CAEs mainly provide well-educated adult learners with courses on general interest and language courses, some of which are oriented to vocational training. CABEs are designed for low-educated or illiterate adults, most of whom are found to be low-literate immigrants (Vermeersch and Vandenbroucke 2009). In addition, eight Dutch Language Houses (Huizen van het Nederlands) have been established since 2002, to help immigrants learn Dutch and integrate into the new society. Like the LINC program in Canada, they do not organize language courses themselves, but rather serve as partnerships between formal DSL training institutions, the Flemish Public Employment Service, the welcome offices and local authorities (Backs 2008, Kurvers and van de Craats 2007). They organize and coordinate the testing and referral of non-Dutch-speaking applicants for an appropriate DSL course.

Whereas literacy education has been integrated and developed on the governmental level in the Flemish community, literacy initiatives for immigrants in the French 
community were driven primarily by volunteer activists in the late 1960s (Maroun 2007). Importantly, in 1983, the voluntary organizations created the Lire et Écrire coordination, which forms an effective literacy network in the French community of Wallonia-Brussels. According to the Lire et Écrire annual report published in 2006, as of 2005, literacy courses in the French community are coordinated by around 10 social welfare schools, 30 public services, and 150 organizations of various sorts, for which around 15,000 people registered (Lire et Écrire 2006). That is, a very small proportion of adult literacy courses are offered by the public sector (Eeman et al. 2012). One thing that draws our attention here is that adult literacy training in the French community does not distinguish between native-born and foreign-born learners. Literacy classes are open to all people over 18 years old, whether Belgian or foreign. Therefore, no such term as "FSL literacy education" seems to be used in the Belgian context, unlike Canada.

\section{Details of implementation of adult literacy education in Belgium}

The issue of adult literacy is considered a serious one in all communities in Belgium. The survey conducted in 1997 shows that 10 percent of the adult population of the French community is poorly literate or illiterate, and that about 15 to 18 percent of the total Flemish adult population is below the level of primary school. According to the Lire et Écrire report in 2006, 20 \% of literacy course participants are Belgium-born people while $80 \%$ of them are foreign-born, with different proportions depending on the regions. As for gender proportion, the majority is female (64\%) (also in Rosen and de Meyer 2008).

As mentioned before, the Flemish community has attempted to systemize and uniform adult literacy education. The first round table in 1993 decided to adopt the Common European Framework of Reference for Languages (CEFR) as a common reference for language assessment. In 1997, the first model placement examination was designed to assess the course participants' language skills and place them in an appropriate level. The second round table held in 2002 adopted a cognitive skills test that can give an indication of course participants' learning potential. Courses offered by CABEs include courses on basic knowledge and skills such as literacy and numeracy skills. Importantly, a specific course that targets very slow learning participants or illiterates was newly created in 2003, separated from courses that target low-educated participants. Participants who have completed courses in a CABE are awarded a certificate or a sub-certificate, and can advance to the next level in a CAE. As the courses at CABEs and CAEs have become more uniform in terms of their goals and course structures since 2003, the learners' transition from one to the other is smooth (Rosen and de Meyer 2008).

In the French community, contents of literacy courses vary depending on organizations, which include acquisition of basic skills (numeracy) and other courses of history, geography, artistic expression, and so on. They have L2 assessment at the time when people register for a language course. However, it is not clear whether such assessment is systemized throughout all the literacy courses at different organizations. Literacy instructors are usually those who majored in education or psychology counseling. The Lire et Écrire report implies that literacy teacher training is available, but it is not clear whether such training is conducted systematically. Unevenness is seen in the distribution of literacy course venues depending on the region in the French community; while 
literacy courses are offered in all municipalities in Brussels, they are available in only about a third of French towns in the Wallonia region in 2005.

\section{Luxembourg}

\section{Functional multilingualism in Luxembourg}

Luxembourg maintains an official trilingualism since its creation. However, unlike Canada and Belgium, Luxembourg's multilingualism is rather unique because language use does not depend on territories but on functions. In 1839, Luxembourg decided to maintain French as the written language of the elite and German as the written language of lay people. Luxembourgish used to be a dialect of German, but the 1984 law on languages (Gouvernement du Luxembourg 1984) upgraded Luxembourgish as the "national" language while stipulating French and German as two "administrative" languages. With this background, German has a long-standing tradition as the language of basic literacy taught at primary school, whereas French serves as the language of educational advancement (Ziegler 2011). Recently, however, French is widely used as the lingua franca among people living and working in Luxembourg, as more and more crossborder commuters come from France and Belgium. Luxembourgish has been used only orally, but recently it grows to be used in informal written communications such as SMSs and emails by Luxembourg natives. In addition to these three languages, English is widely used in many contexts with the rapid growth of the foreign population, while Portuguese is the minority language of the largest foreign residents group.

As a consequence of functional multilingualism in Luxembourg, typical native Luxembourgers and many residents of Luxembourg are truly plurilingual in the sense that they use different languages in parallel. They receive official administrative letters in French and police reports in German, watch TV programs usually in Luxembourgish or German, and order food in French in restaurants. When it comes to immigrants, they should be able to deal with the multiple languages and their alphabetic orthographies in order to participate in Luxembourg society. The first thing for them to do is to decide which language to learn among the multiple languages. Their decision usually depends on their purposes (employment, education, naturalization, etc.) and the region where they settle. That is, if an immigrant's goal is to get a job or receive higher education, she is required to have proficiency in both German and French in most cases. If she wants to obtain a Luxembourgish nationality, she must learn Luxembourgish. In addition, immigrants who settle in the northern part of the country would find it more useful to learn German than French while those who settle in the central or southern region would end up learning French. However, many immigrants, especially LESLLA immigrants simply do not know where to start and cannot decide which language to learn due to lack of information, motivation, and time.

\section{Means of integration}

According to recent figures from STATEC (2011), foreigner population in Luxembourg has increased from $43.1 \%$ in January 2010 to $44.7 \%$ in January 2011. While the majority of the foreign population is composed of European citizens ( $86 \%$ of the total foreign population), such as Portuguese, French, Italians, and Belgians, the increase of nonEuropean population (14\% of the total foreign population) is worth noticing. 
As the issues of integration grow to be crucial in Luxembourg, the law of 16 December 2008 (the Law, henceforth) on the reception and integration of foreigners was passed, which stipulates that the process of integration is reciprocal between immigrants and the host society. According to the Law, the Luxembourg Reception and Integration Agency (Office Luxembourgois de l'accueil et l'intégration or OLAI) has been created under the Ministry of Family and Integration (Ministère de la Famille et de l'Intégration). OLAI carries out various measures to facilitate smooth integration and participation of immigrants in the society of Luxembourg by cooperating with other public institutions, municipalities, and civil society actors. One of the most important measures implemented by OLAI is the Reception and Integration Contract (Contrat d'accueil et d'intégration or CAI), launched officially in October 2011. CAI offers language training as well as an orientation session, civil training, and social care for both newcomers and long-term residing immigrants in Luxembourg. For the maximum of 2 years, applicants of CAI can benefit from a reduced registration fee (10 euros) for Luxembourgish, German and French courses, and exemption of elective civil courses that are required for naturalization.

\section{Adult language and literacy education frameworks}

Adult language education in Luxembourg is coordinated by the department of Adult Education (Service de la formation des adultes, or SFA) of the Ministry of National Education and Vocational Training (Ministère de l'Éducation nationale et de la Formation professionnelle). SFA coordinates language courses through its national language center, the National Institute of Languages (Institut National des Langues or INL) or through the collaboration with schools, municipalities, and non-profit organizations. Those language courses are designed to enable course participants to acquire proficiency so that they can integrate to the social, economic, and cultural life of Luxembourg. Job seekers who are registered at the Agency for Development and Employment (L'Agence pour le développement de l'emploi, or ADEM) and immigrants who signed up for CAI can benefit from a reduction of the registration fee for language courses.

SFA also coordinates adult literacy courses through Additional Adult Education (Instruction complémentaire d'adultes, or ICA), which organizes courses that prepare the same diplomas and certificates that are issued in regular education in Luxembourg. People who have not had the opportunity to complete their initial education can benefit from those courses at no charge. This framework offers courses of general interest and social promotion, which include literacy courses.

However, with a strong belief that Luxembourg is a highly literate society, there has not been enough attention to adult literacy education as well as immigrants' L2 literacy education. There are no statistics available on low literacy or illiteracy in Luxembourg that the public can access (Ewerling: Illiteracy in Luxembourg: reading and writing difficulties of adults in Luxembourg, unpublished). According to our own investigation, adult literacy education is offered mainly by the private sector. INL hosts only one literacy course in French. In addition, a handful of literacy courses are offered at municipalities through non-profit organizations. Due to lack of the relevant statistics, it is hard to know how many people are registered in the literacy classes and who they are. However, Ewerling importantly observes that German literacy courses usually have Luxembourgish natives while most foreign literacy learners register for French literacy courses. That is, even 
though no literacy courses explicitly target immigrant L2 literacy learners, the multilingual landscape of Luxembourg spontaneously leads those immigrants to choose to learn French literacy as the lingua franca of Luxembourg. We will see in Section 'A case study' that Ewerling's observation holds for our case study, where only immigrant learners were found to be participating in the French literacy course that we observed.

\section{Summary}

So far, we have seen the linguistic integration policies and implementation of adult (L2) literacy training in Canada, Belgium, and Luxembourg. The comparison is summarized in Table 1 below.

As you can see in Table 1, there is no sufficient data that is available on adult literacy as well as immigrant literacy in Luxembourg. It is hard to find an overview of how many adult literacy courses are currently held and where they are held. More importantly, it is hardly known how those courses are implemented: which of the three official languages are taught, how successfully the courses maintain their learners, how many of the learners are low-literate immigrants, and how much struggle those immigrants have in those courses. This insufficiency of data motivated us to have a participatory observation on an adult literacy course, which will be introduced in the following section.

\section{A case study}

\section{Background}

This section reports our participatory research on a French literacy course for adults in Luxembourg. The French literacy course took place in a city in the south of the country, launched in October 2011 by an NGO, Inter-Actions. Our participatory research was conducted from May 2012 to June 2012. During that period, the authors of this paper observed and participated in seven sessions of its two-hour classes, in order to understand the actual implementation of adult literacy training in Luxembourg, including the profile of the course participants, the organization of the classes, teaching methods and material, and problematic areas for learning. After each two-hour class, we had a debriefing and discussion session with the teacher, where we exchanged information on possible ways to improve the learners' learning processes and practices. While observing the literacy classroom, we applied a few linguistic interventions to the learners in order to assess their literacy skills and processes. The interventions are divided into phonological interventions and interventions on a textual level, whose detail will be given later. In addition, we also conducted socio-linguistic background interviews with the participants to obtain their profiles. Finally, a rough assessment of their oral and literacy skills in French was made in the course of our class observations and interventions, because there was no such assessment provided by the teacher.

\section{The learners}

In the French literacy course, we were able to observe five low-literate learners. At the initial stage of the course in October 2011, 11 people signed up, but six of them had stopped showing up by the time we joined the course in May 2012. As summarized in Table 2, all of the remaining learners were female immigrants, who had been living in 
Table 1 Comparison of adult (L2) literacy education in Canada, Belgium, and Luxembourg

\begin{tabular}{|c|c|c|c|c|}
\hline & \multirow[t]{2}{*}{ Canada } & \multicolumn{2}{|c|}{ Belgium } & \multirow[t]{2}{*}{ Luxembourg } \\
\hline & & Dutch-speaking community & French-speaking community & \\
\hline 1. Types of multilingualism & Territorial bilingualism & \multicolumn{2}{|c|}{ Territorial multilingualism } & Functional multilingualism \\
\hline $\begin{array}{l}\text { 2. Implementation of L2 literacy } \\
\text { training }\end{array}$ & By each province and territory & \multicolumn{2}{|c|}{$\begin{array}{l}\text { By each language community } \\
\text { (the Flemish and the French communities) }\end{array}$} & On the governmental and private levels \\
\hline 3. Framework of L2 literacy training & $\begin{array}{l}\text { Integrated into Adult Basic Education } \\
\text { (ABE) }\end{array}$ & Independent of general $\mathrm{ABE}$ & Integrated into $\mathrm{ABE}$ & Integrated into Additional Adult Education \\
\hline $\begin{array}{l}\text { 4. Coordinating institution for L2 literacy } \\
\text { training }\end{array}$ & $\begin{array}{l}\text { LINC (Language Instruction for } \\
\text { Newcomers to Canada) on federal level }\end{array}$ & $\begin{array}{l}\text { Dutch Language Houses on } \\
\text { governmental level }\end{array}$ & $\begin{array}{l}\text { Private organizations and } \\
\text { networks }\end{array}$ & $\begin{array}{l}\text { Mainly private organizations, except for one } \\
\text { course at the National language center }\end{array}$ \\
\hline \multirow[t]{3}{*}{ 5. Public discussion or survey } & LSUDA (1989) & \multirow{3}{*}{$\begin{array}{l}\text { Round table conferences } \\
(1997,2002)\end{array}$} & \multirow[t]{3}{*}{ Lire et Ecrire reports } & \multirow[t]{3}{*}{ Not available } \\
\hline & IALS (1994) & & & \\
\hline & IALSS (2003) & & & \\
\hline 6. Guideline for L2 literacy curriculum & Canadian Language Benchmarks & $\begin{array}{l}\text { Decisions made at the Round table } \\
\text { conferences: e.g., CEFR as a common } \\
\text { reference for language assessment } \\
\text { (1993), Cognitive skills test (2002) }\end{array}$ & Not available & Not available \\
\hline 7. Placement test & Available & Available & Available & Not available \\
\hline \multirow[t]{4}{*}{ 8. Skills taught at adult literacy courses } & - Literacy skills & - Literacy skills & \multirow{4}{*}{$\begin{array}{l}\text { Depend on course organizing } \\
\text { bodies }\end{array}$} & \multirow[t]{4}{*}{ Not known } \\
\hline & - Numeracy skills & - Numeracy skills & & \\
\hline & - Pre-reading skills & & & \\
\hline & - Study skills & & & \\
\hline
\end{tabular}


Luxembourg for 1 - 20 years. Some of them had received formal schooling ranging from 1 to 4 years, when their education was interrupted due to family issues or poverty. One participant never had formal education.

According to our subjective assessment, their oral proficiency of French greatly varies from poor to very good. Aicha's L1 is French, so she could express herself fluently and spontaneously without much obvious searching for expressions. Angela and Inas could understand the main points of the input by the teacher, and participate in the discussion of the classes. Sara could understand sentences and frequently used expressions, but had difficulty in describing aspects of her environment and ideas. Manna's oral French was even lower than Sara, only managing to respond to very basic questions, such as Tu bois du thé ou du café? 'Do you drink tea or coffee?', with Non, merci.

Their literacy skills in French were very poor, except for one learner. The levels of French literacy skills seem to coincide roughly with their L1 literacy skills. For most of them, they were not able to read a whole sentence on their own. Aicha, Inas, and Sara could manage to read short words, but not longer ones. Aicha could read words that are short in length and frequently used, such as $\langle$ une $\rangle,\langle$ femme $>,\langle$ comme $>$, and $<$ elle $>$. However, she could not read words that are longer or contain consonant clusters, such as <épouser $>$ and $<$ pleure $>$; she pronounced $<$ pleure $>$ as [pa], [pə], or [per]. For $<$ épouser $>$, she read it as [epul] and [epu]. Inas could manage to read words that have a syllable structure of $\mathrm{CV}$, such as $<\mathrm{la}>$ and $<$ se $>$. However, she had difficulties in reading words with coda, such as $<$ avec $>$. Sara could read short words like $<$ avec $>$ and $<$ en $>$, but not longer ones. She pronounced $<$ manger $>$ as [mafen], and $<$ poivron $>$ as [po]. Manna had extreme difficulty in reading almost every word, except for one-letter word, such as $<a>$ and $<$ à $>$. She couldn't even manage to read simple ones like $<\mathrm{le}>$ or $<$ les $>$. Angela was the only one who could manage to finish reading a whole sentence without the help of the teacher, such as Aujourd'hui c'est jeudi.

\section{Observation on the teaching material, the methods, and the learners' practices}

We observed that the main teaching material was written, namely handouts that contained vocabulary, texts, and pictures. The handouts were drawn from a French textbook developed in France, which seemed designed for immigrant learners, having characters of a North African origin (see Fig. 1).

The text material contained various types of fonts, which were normally very small in size. Besides the written material, a white board was frequently used for the teacher to write down words and phrases that appear in the handouts. Color pencils, scissors, and

Table 2 Overview of the participants of the French course

\begin{tabular}{|c|c|c|c|c|c|c|c|}
\hline Name & Age & $\begin{array}{l}\text { Duration of stay } \\
\text { in Luxembourg }\end{array}$ & $\begin{array}{l}\text { Prior } \\
\text { education }\end{array}$ & Language of origin (L1) & $\begin{array}{l}\text { Literacy in } \\
\text { L1 }\end{array}$ & $\begin{array}{l}\text { Oral } \\
\text { French }\end{array}$ & $\begin{array}{l}\text { Literacy } \\
\text { in French }\end{array}$ \\
\hline Aicha & $30 \mathrm{~s}$ & $5-6$ years & 2 years & French, A dialect of Ivory Coast & No & Very good & Poor \\
\hline Angela & $40 \mathrm{~s}$ & 5-6 years & 4 years & Cape Verdean & Yes & Fair & Fair \\
\hline Inas & 47 & 20 years & None & Moroccan Arabic & No & Fair & Poor \\
\hline Sara & 33 & $1-2$ years & $1-2$ years & Brazilian Portuguese & Limited & Poor & Poor \\
\hline Manna & 41 & 3-4 years & 2 years & Nepalese & Claims yes & Very poor & Very poor \\
\hline
\end{tabular}




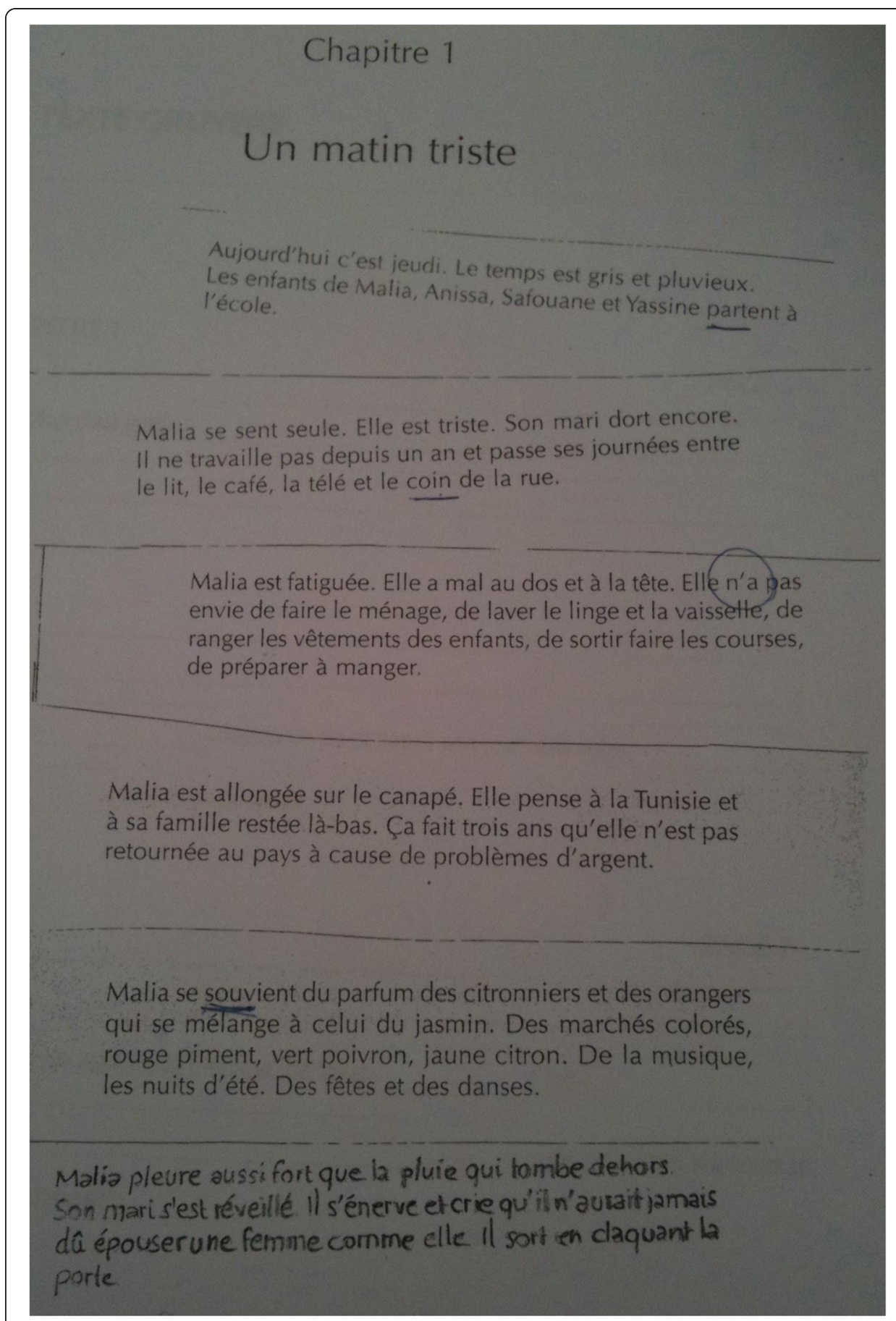

Fig. 1 A reading material with text

glues were also used for the learners to do exercises with. A computer was used for a limited purpose like doing supportive phonetic exercises.

At the time when we started observing the course, the course was mainly about reading and comprehending a story about a woman from North Africa. The teacher explained to us that she had done alphabetic exercises (i.e., grapheme-phoneme correspondence) and vocabulary exercises before we joined the course. The teacher distributed 
the story in print to the learners, and invited them to read the story (see Fig. 1). She then asked them to match each paragraph of the story with one of the pictures that was printed on a separate paper. Also, there was an exercise to reorganize the paragraphs in a chronological order and a fill-in-the-blank exercise (see Fig. 2).

When the students were asked to read the text out loud individually by the teacher, they had difficulty in recognizing small-sized fonts in the textbook. Also they did not recognize various types of cursive writings of the same letter. Manna even got lost in reading line by line; she frequently skipped one line after another or repeated the same line again. As briefly described before regarding their literacy level, most of the students required the teacher's help to finish reading a sentence, which made the duration of the reading exercise more than an hour.

In writing as well, it took quite long for them to copy the teacher's writing on the white board. In addition, it was common for the learners to mix around upper-case letters and lower-case letters; even those learners who already had knowledge about where to write upper-case letters were often confused in their actual writing. In general, the learners (in particular, Manna) seemed uncomfortable with holding and writing with a pen or a pencil, and were not good at making pen strokes.

During the classes, the majority of the learners were passive and remained silent. All of them possessed a cell phone of their own, but almost no one was using text messages. One of the participants, Aicha, even had a smart phone and was eager to use its

\section{LE TEXTE GRUYERE}

\section{$1 / 5$}

CHAPITRE 1

- PAGe 5.

Aujourdhui c'est jeudi.

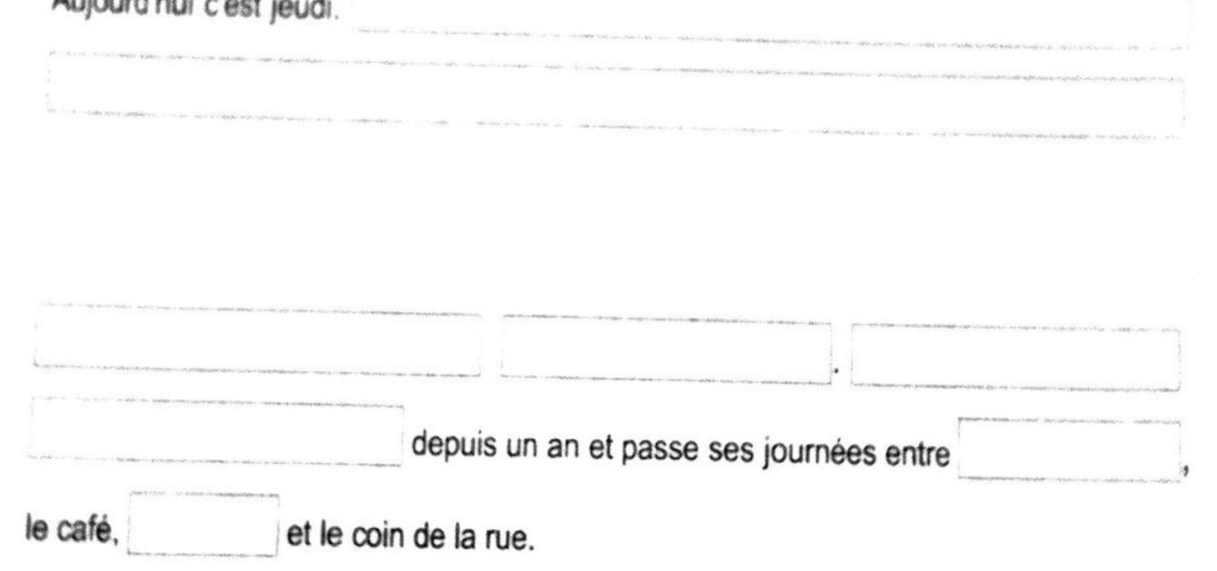

Fig. 2 Fill-in-the-blank exercise 
many functions including text messaging, but she had no knowledge how to utilize them or required assistance when using them.

\section{Interventions}

After having made a general observation on the course, we carried out a few interventions aiming at understanding the specific situation of the learners. Our interventions were on two levels: the phonological level and the textual level. On the phonological level, we conducted a so-called "write what you hear" practice and a phonological awareness practice. On the textual level, we did a joint writing activity.

The "write what you hear" practice was designed to identify and assess the students' phonological and spelling skills. The authors pronounced their names, namely, 'Jin', and 'Gudrun', out loud several times, and asked the participants to try to write them down on the white board. For the name 'Jin', Angela gave a first try with $\langle\mathrm{DJiNi}\rangle$, and then Sara wrote $<$ Dima $>$ while hesitating (see Fig. 3). Aicha was asked to try Gudrun's name; she first wrote $<$ Gourdm $>$ and then $<$ Gournd $>$. With the help of the French teacher and researchers, who provided examples like drapeau that contains a [dr] sound, Aicha finally managed to write the consonant cluster $<\mathrm{dr}>$ as in $<$ Goudroun $>$ (see Fig. 4). Inas initially refused to write anything, but after having watched other participants attempt to produce something, she, still hesitating, tried to write the name $<$ Malia $>$ from a reading material. She first wrote $<\mathrm{MliA}>$, and then revised her writing from $<\mathrm{MAilA}>$ and $<\mathrm{MLAi}>$, to $<\mathrm{MALiA}>$, with the assistance of the teacher and the researchers.

For the phonological awareness practice, the name "Anissa" from the reading material was divided into three syllables, $\langle\mathrm{a}\rangle,\langle\mathrm{ni}\rangle$, and $\langle\mathrm{ssa}\rangle$, by the teacher. The students were asked to provide words that begin with each syllable sound. They, with the help of the researchers, gave words like aller, allo, and ana for $<\mathrm{a}>$, and nicole, nicolas, nick, and niveau for $<\mathrm{ni}>$, as shown in Fig. 5. As for $<\mathrm{ssa}\rangle$, they provided words like samedi, salon, Samir, savon, and salut.

A joint writing activity was conducted after the phonological awareness practice was done. The students were instructed to make a story by using those words that had been collected in the phonological awareness practice. Aicha and Inas managed to make

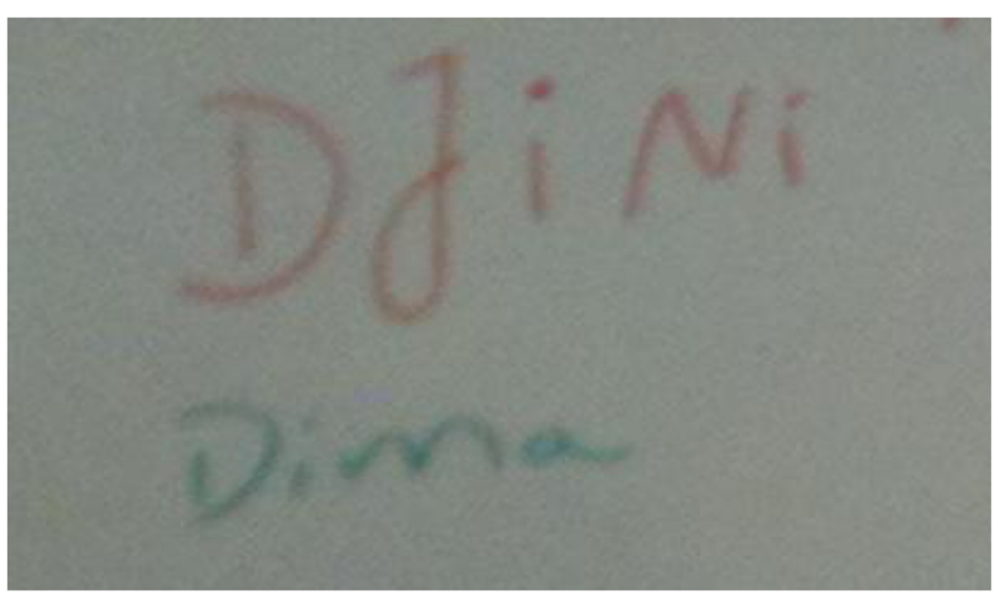

Fig. 3 Writing of "Jin" by Angela and Sara 


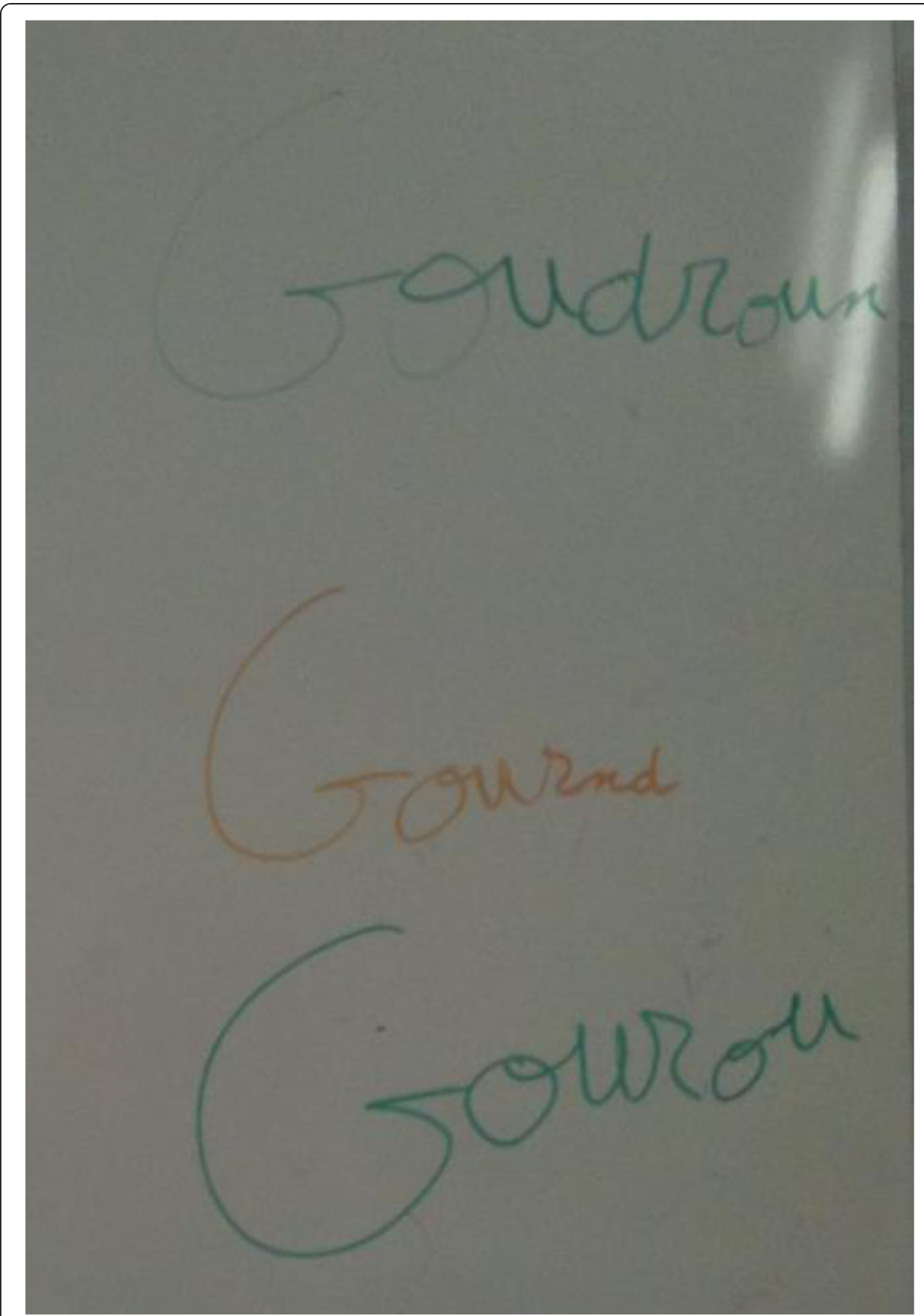

Fig. 4 Writing of "Gudrun" by Aicha

short sentences. Sara only listed several words but could not successfully form a sentence. Manna remained passive and tried to write one or two words. By working jointly with all the participants, a story was made like the following: Aujourd'hui, c'est Samedi. Samir va au salon manger des sardines et du salami. La salopette est sale. (see Figs. 6 and 7).

From these interventions that were conducted for a total of four sessions, we observed that the rate of the students' progress greatly varied. Our assessment is based on a dictation test result, review of a homework assignment that is similar to the joint writing activity, and activeness in participating in class activities. We speculate that their progress is 


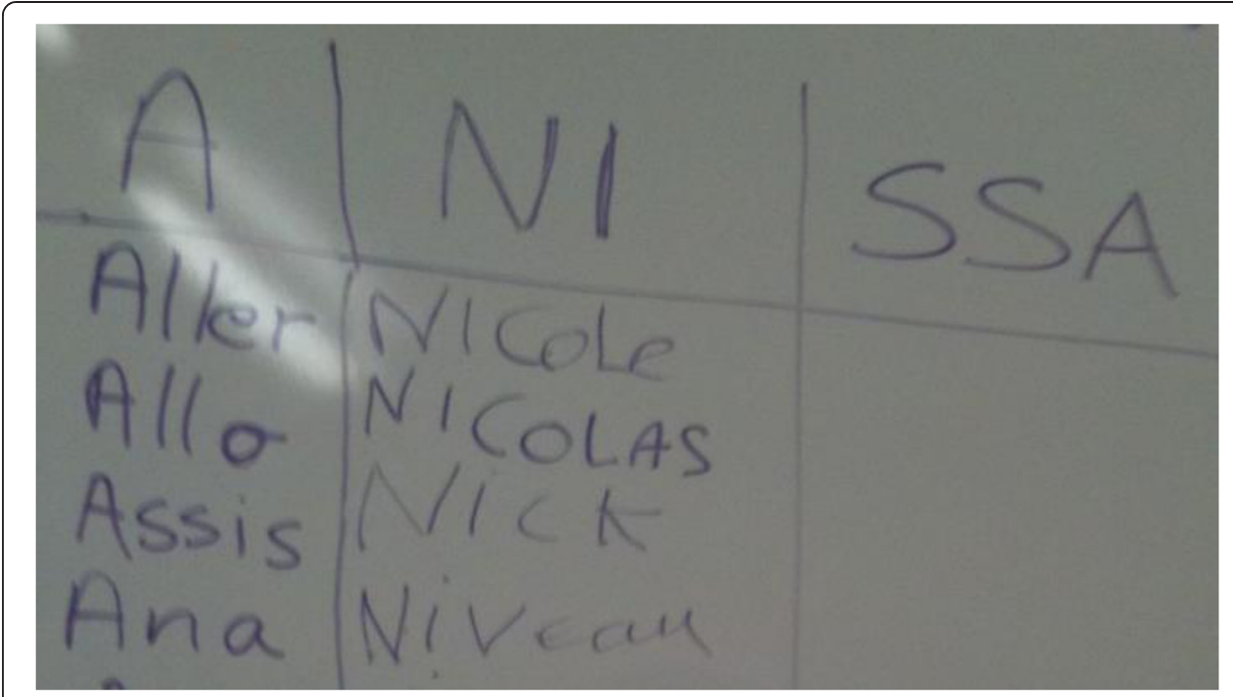

Fig. 5 A phonological awareness practice

possibly related to their oral proficiency in French, duration of formal education, and their confidence level. For instance, Aicha whose oral French was near native showed faster progress in literacy acquisition than others. Angela's progress was noticeable in dictation and homework; it is possibly because she had more years of formal schooling (4 years) than the others. We also observe that the learners' levels of confidence or empowerment played an important role. Inas and Manna, who usually withdrew themselves and were hesitant to ask or answer questions exhibited slower progress.

\section{Findings and recommendations}

This section is concerned with providing our findings and recommendations on adult literacy education in Luxembourg, based on our research in section 'Luxembourg' and class observation presented in section 'A case study'. Our recommendations are inspired by the policies and practices of Canada and Belgium that we looked into in sections 'Canada' and 'Belgium'.

\section{About L2 literacy course curriculum}

We found that all of the participants of the French literacy course were long-residing or newly-arrived immigrants, which confirm Ewerling's report that German literacy courses usually have Luxembourgish natives while most L2 literacy learners register for French literacy courses. Therefore, the course design for French and German (or Luxembourgish) literacy courses should be different. That is, French L2 literacy courses must be designed for LESLLA learners, by, for example, referring to FSL literacy material developed in Quebec or in France, adopting written material that contains bigger letters, identical clear fonts, and a large number of pictures. Furthermore, as practiced in Canada and Belgium, L2 literacy courses are recommended to teach numeracy skills and study skills. 


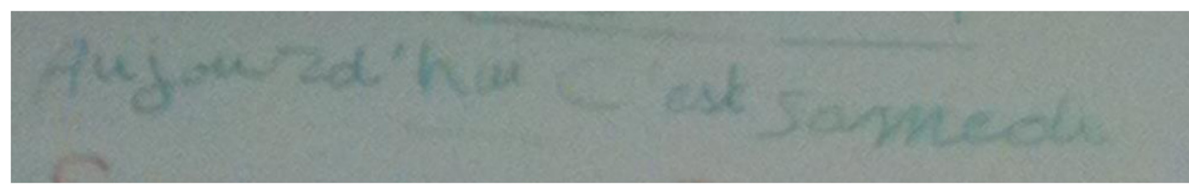

Fig. 6 Joint writing activity 1: Aicha's writing on the board

\section{About teaching material and methods}

The French literacy course that we observed seemed too dependent on paper, pencil and board, with rarity of use of computers or video material, etc. It is recommended to utilize more various devices of technology, such as computers and projectors. Use of cell phones or smart phones are also recommended in order to meet the learners' desire to manipulate more functions of their devices and give more dynamicity to the class. It is desired to develop various types of exercises that promote phonological awareness, as the course was mainly focused on story reading and comprehension, which can be difficult for LESLLA learners to follow. Finally, given that all of the course participants were female, many of whom tend to be passive and silent in class, strategies to promote their empowerment will be desired.

\section{About the general policy of adult (L2) literacy education in Luxembourg}

First, we saw that adult literacy education and particularly L2 literacy education policies were able to be made on the basis of good survey and public discussions in Canada and the Flemish community of Belgium. As regards to Luxembourg, national statistics and surveys on adult literacy will be highly desirable. As seen in section 'Luxembourg', there is no systematic pooling of information on how many adult literacy courses are offered across the country, how many participants are registered for those courses and who those participants are. It is partially because the country is too small, and also because of the small number of the yet very different profiles of low literate adults. Luxembourg can conduct a national investigation on the demand of adult literacy education and LESLLA education, and a review of the existing adult literacy courses as to how effective they have been in terms of educating literacy and promoting integration and empowerment. Then it can organize literacy course offerings accordingly, in terms of the number and locations of courses. In that way, the unevenness of the current course offerings across the country can be resolved.

Second, it is required to systemize and better coordinate the adult literacy courses that have been created spontaneously on demand and mostly offered by municipalities through non-profit organizations. If it is too difficult, at least a standardized assessment tool should be available, such as Canada's Canadian Language Benchmarks, and it should be implemented at every literacy course venue. Currently, only the literacy course at INL does an

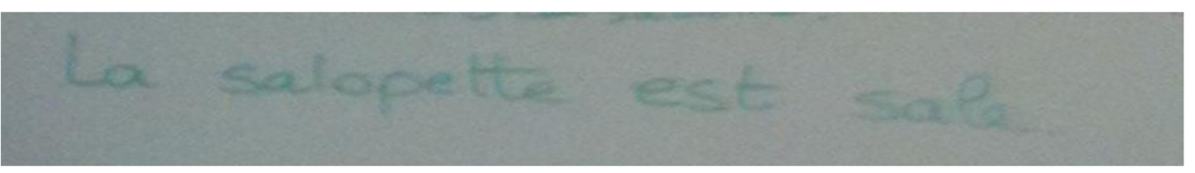

Fig. 7 Joint writing activity 2: Teacher's writing of Inas's suggestion 
assessment test while the others that are managed by non-profit organizations do not do a systematic placement test. As it is not desirable to allocate learners with good and poor oral proficiencies in one class unless under a well-planned condition, assessment in L2 at registration for a course will be highly desired. In addition, a sociolinguistic background on learners will be good to have for the design of a course.

Third, another good practice in Canada and Flanders is that they have a particular body that promotes, organizes, and coordinates language learning and sociolinguistic integration of immigrants. However, Luxembourg does not have such a one-stop point of contact for immigrants yet, which leads to slowing down integration. Even though OLAI takes charge of helping to make smooth the social integration of immigrants, its mission is too wide to concentrate on adult literacy education. In addition, its service has been poorly advertised to reach the target group of low-literate learners.

Finally, teacher qualification and training should be available. Currently, adult literacy teachers in Luxembourg are not required to hold a specific degree or training in adult literacy education. An effective training on learner profile and (L2) literacy curriculum and methods will be required. Ideally, such training should be systematized across literacy institutions in the country.

\section{Concluding remarks}

In this paper, we have discussed LESLLA education within the sphere of adult literacy education in the multilingual setting of Luxembourg. We looked into the current states of the linguistic integration policies and practices of Luxembourg by observing a French literacy course as a case study. With insights from the good practices of two other multilingual countries, Canada and Belgium on LESLLA education, we recommended several policy and practice options, including conducting national surveys on adult literacy, systematizing literacy assessment and course curriculum, building a particular body to organize and coordinate immigrants' language learning, and developing literacy teacher training.

We note that there are general problems concerning literacy education of immigrants, existing in every country that we have discussed. First, even though language assessment is carried out for language course applicants in Canada and Belgium, no ideal assessment tools for L2 literacy are available because standardized tests are usually not suitable for LESLLA learners. Second, even though researchers and educators agree that L1 literacy assessment is desirable, implementing L1 literacy assessment is not an easy matter. Third, in all three countries, funding resources for adult literacy education are very limited and literacy teachers are usually poorly paid. Accordingly, availability of teacher training is also an issue. To conclude, multilingual countries are particularly challenging to LESLLA learners, and thus their specific situations and needs should be better understood in order to provide them with suitable schemes of support in accordance with their particular multilingual profiles.

\section{Endnotes}

${ }^{1}$ The term LESLLA comes from the international forum 'LESLLA' (www.leslla.org), where interdisciplinary research is brought together on adult immigrants learning to speak and write a language other than their native language.

${ }^{2}$ For the concept of word, Kurvers et al. (2007) compared non-literate children, nonliterate adults and low-literate adults, and Onderdelinden et al. (2009) compared non- 
literate and low-literate adults. Onderdelinden et al. (2009) revealed that "those who cannot read nor write, whether adults or children, do not have a clear word concept", but that literacy education, e.g., two years of primary education can enhance their awareness of words. Thanks to an anonymous reviewer for letting us know about these studies.

${ }^{3}$ However, British Columbia, Manitoba, and Quebec provide their own programs, and Quebec offers only French as a second language.

${ }^{4}$ The relevant website is www.language.ca.

${ }^{5}$ It may be comparable to the Common European Framework of Reference for Languages (CEFR), even though CEFR has no standards or levels defined for literacy. It assumes that all adults have a primary school level of education and can read and write in their L1. Thanks to a reviewer for pointing this out.

${ }^{6}$ In the following, we discuss adult literacy education in the Flemish and the French communities only, because the German community is quite small and therefore does not seem to have basic education centers of its own.

${ }^{7}$ http://ec.europa.eu/ewsi/en/resources/detail.cfm?ID_ITEMS=11438

${ }^{8}$ Another mission of OLAI is to organize social assistance to foreigners who are not qualified for aid and existing allocations and applicants for international protection, as defined by Act of 5 May 2006 on the right of asylum seekers.

${ }^{9}$ As for the other actions by CAI, the orientation session is a two hour session, where an immigrant goes over a questionnaire for their social and professional situation, and receives various documents regarding the country and integration. A translation service is available for this orientation session. The civil training courses are offered in several languages for a total of six hours. They are organized by OLAI together with the Ministry of Education and Vocational Training and municipalities, and generally open to the public. In addition, an optional social care is available upon the request of participants of CAI.

${ }^{10}$ In addition, the Department of Vocational Training (Service de la Formation professionnelle) organizes courses for job seekers registered with the ADEM to continue education and training.

${ }^{11}$ This organization runs a project called Project Ensemble, which aims to develop an intercultural community by promoting a successful integration in terms of social, cultural, and political aspects. For more information, refer to its website, http://www.interactions.lu/projet-ensemble-travail-communautaire/.

${ }^{12}$ The names of the participants here are all pseudonyms.

${ }^{13}$ Spellings are indicated with $<>$, and pronunciations with [ ].

${ }^{14}$ As an anonymous reviewer suggested, having learners with different oral proficiencies can sometimes work if the teacher is fully aware of the levels of students, group them into subgroups, and give tasks to each group or individual. However, if these conditions are not guaranteed, such a class may not be beneficial, particularly for students of lower levels.

Competing interests

The authors declare that they have no competing interests. 


\section{Authors' information}

$J C$ received her PhD in Linguistics from the University of Pennsylvania. She is currently a post-doctoral researcher at multi-LEARN Institute in Luxembourg, where she conducted two European projects: the first one on low-literate and Asian immigrants' linguistic integration in Luxembourg, and the other one on the reception conditions for asylum seekers in Luxembourg. Her research interests include second language acquisition, pragmatics, multilingual education development and characteristics of (multi-) literacies in multilingual settings, and linguistic integration of immigrants and refugees.

GZ currently works at the Ministry of Education of Luxembourg, and is the principal investigator of the two European projects mentioned above in multi-LEARN Institute. She was appointed Associate Professor of Learning, Interaction and Multilingualism at the trilingual University of Luxembourg in 2006, where she created and directed the Research Master - Learning and Development in Multilingual and Multicultural Contexts (2007-2011), a program which figured on the list of innovative approaches for multilingual education by UNESCO, Institute for Lifelong Learning (Ziegler 2011). She received her PhDs from Sorbonne Nouvelle and Saarland University, specializing in language learning and interaction. Her international research projects focus on interaction, multilingual language development, teacher education in multilingual contexts, professional development in lingua franca contexts and the construction of disciplinary knowledge in multicultural and multimodal learning environments.

\section{Acknowledgements}

This research was supported by the European Integration Fund, the Luxembourg Reception and Integration Agency, and multi-LEARN institute, Luxembourg. The authors thank Janelle Yang-Fellenz for supporting the proofreading. The authors are grateful to the participants of the case study introduced in section 'A case study'. The authors also would like to express their gratitude to the audience at the 10th LESLLA conference in Nijmegen, the Netherlands in August, 2014, for their valuable comments.

This research is part of the three-year project "multi-LITERACIES" (2012 - 2015), which was funded by the European Integration Fund and the Luxembourg Reception and Integration Agency. This paper was presented at the 10th LESLLA conference, held in Nijmegen, the Netherlands, in August 2014.

\section{Author details}

${ }^{1}$ multi-LEARN Institute, Luxembourg, Grand Duchy of Luxembourg. ${ }^{2}$ Ministry of Education of Luxembourg and multi-LEARN Institute, Luxembourg, Grand Duchy of Luxembourg.

Received: 19 December 2014 Accepted: 18 May 2015

Published online: 29 May 2015

\section{References}

Backs, J. 2008. Policy on LESLLA learners in Flanders. Proceedings of the fourth Annual Forum, Low-Educated Second Language and Literacy Acquisition (LESLLA), 159-169. Utrecht, The Netherlands: LOT.

Bialystok, E. 2001. Bilingualism in development: language, literacy, and cognition. New York: Cambridge University Press.

Center for Canadian Language Benchmarks. 2000. ESL for literacy learners. http://www.language.ca/documents/ esl_for_literacy_learners_april_2010_lowres.pdf. Accessed 11 Apr. 2013.

Center for Literacy of Quebec. 2008. ESL and literacy: finding common ground, serving learners' needs. http:// www.centreforliteracy.qc.ca/sites/default/files/ESLLiteracy.pdf. Accessed 1 Oct. 2013.

Citizenship and Immigration Canada. 2013. Welcome to Canada - What you should know. http://www.cic.gc.ca/english/ pdf/pub/welcome.pdf

Coalition, Ontario Literacy. 2007. Creating a bridge : a snapshot of ESL literacy in Ontario. Toronto, ON: Executive summary,

Eeman, L, L Vermeersch, S Groenez, A Vause, and I Raemdonck. 2012. Projets de prevention dans le context familial Etude d'évaluation des projets soutenus par le Fonds de bpost pour l'Alphabétisation. HIVA-Katholieke Universiteit Leuven and GIRSEF-Université catholique de Louvain, Belgium. http://www.kbs-frb.be/uploadedFiles/2012-KBS-FRB/ 05\%29 Pictures, documents and external sites/09\%29 Publications/PUB2012 3105 Bpost.pdf. Accessed 1 Oct. 2013.

Grieve, K. 2007. Assessment for whom and for what? Stepping back to ask important questions about assessment. In Measures of success, ed. P Campbell, 123-158. Edmonton, Alberta: Grass Roots Press.

Hamers, J, and M Blanc. 2000. Bilinguality and Bilingualism. Cambridge: Cambridge University Press.

Kurvers, J, and I van de Craats. 2007. Literacy and second language in the low countries. In Proceedings of the fourth Annual Forum, Low-Educated Second Language and Literacy Acquisition (LESLLA), 17-23. Roundtuit Publishing: Durham, UK.

Kurvers, J, R van Hout, and T Vallen. 2007. Literacy and word boundaries. In Low educated second language and literacy acquisition: research, policy and practice. Proceedings of the second annual forum, ed. N Faux and $\mathrm{H}$ Major, 44-64. Richmond, VA: The Literacy institute. 21 p.

Lire et Écrire. 2006. Questions sur l'alphabétisation - Réponses aux 59 questions les plus fréquentes. A brochure published by Lire et Écrire Communauté française a.s.b.l. and Lire et Écrire Wallonie a.s.b.l. Namur, Belgium.

Maroun, E. 2007. Professional development in the field of literacy and basic education - State of the art in Belgium, National Agency to Fight Illiteracy (ANLCI), under the project titled « professionalization of literacy and basic education - Basic modules for teacher training - TRAIN ». http://www.die-bonn.de/train/english/materials/ TRAIN_Belgium_National\%20Report_Final\%20Version.PDF. Accessed 1 Oct. 2013.

Onderdelinden, L, I van de Craats, and J Kurvers. 2009. Word concept of illiterates and low-literates: worlds apart? In Low-educated adult second language and literacy acquisition, Proceedings of the 4th symposium, ed. I van de Craats and J Kurvers, 35-48. Utrecht: LOT.

Organization for Economic Co-operation and Development. 1995. Literacy, economy, and society. Paris: OECD, Center for Educational Research and Innovation. 
Reder, S and M Cohn. 1984. A study of English language training for refugees in the United States - Phase II: Classroom observation and community survey. U.S. Department of Health and Human Services, Social Security Administration, Office of Refugee Resettlement. http://files.eric.ed.gov/fulltext/ED258474.pdf. Accessed 7 Oct. 2013.

Rosen, DJ, and I de Meyer. 2008. Case study: Belgium (Flemish Community). Teaching, Learning and Assessment for Adults: Improving Foundation Skills. OECD Publishing. http://dx.doi.org/10.1787/172017435434. Accessed 27 Nov 2013.

Selinker, L. 1972. Interlanguage. International Review of Applied Linguistics 10: 209-231.

Shohet, L. 2001. Adult learning and literacy in Canada. Review of adult learning and literacy 2: ch.6. http:// www.ncsall.net/index.html@id=558.html. Accessed 16 Aug 2013.

STATEC. 2011. Recensement de la population 2011. http://www.statistiques.public.lu/en/publications/series/rp2011/ index.html

Statistics Canada, Human Resources and Skills Development Canada, US National Center for Education Statistics, Organisation for Economic Co-operation and Development. 2005. Adult Literacy and Skills Survey (IALSS)

Van de Craats, I, J Kurvers, and M Young-Scholten. 2006. Research on Low-Educated Second Language and Literacy Acquisition. In Low-Educated Adult Second Language and Literacy Acquisition. Proceedings of the Inaugural Symposium, ed. I van de Craats, J Kurvers, and M Young-Scholten, 7-23. Utrecht, The Netherlands: LOT.

Vermeersch, L, and A Vandenbroucke. 2009. The access of adults to formal and non-formal adult education. Country report: Belgium (Flemish Community). LLL2010 project 5. Leuven: K.U.Leuven (University of Leuven) - Higher Institute for Labour Studies.

Wallace, C. 1992. Reading. Oxford: Oxford University Press.

Young-Scholten, M, and N Strom. 2006. First-time L2 readers: Is there a critical period? In Low-Educated Adult Second Language and Literacy Acquisition. Proceedings of the Inaugural Symposium, ed. I van de Craats, IJ Kurvers, and M Young-Scholten, 45-68. Utrecht, The Netherlands: LOT.

Ziegler, G. 2011. Innovation in learning and development in multilingual and multicultural contexts: principles learned from a higher educational study programme in Luxembourg. International Review of Education 57: 685-703.

\section{Submit your manuscript to a SpringerOpen ${ }^{\circ}$ journal and benefit from:}

- Convenient online submission

Rigorous peer review

- Immediate publication on acceptance

- Open access: articles freely available online

- High visibility within the field

Retaining the copyright to your article 